Article

\title{
Cyberspace Knowledge Gaps and Boundaries in Sustainability Science: Topics, Regions, Editorial Teams and Journals
}

\section{Stanley D. Brunn ${ }^{1,2}$}

1 School of Tourism and Geographical Sciences, Yunnan Normal University, Kunming 650500, China

2 Department of Geography, University of Kentucky, Lexington, KY 40506, USA; E-Mail: brunn@uky.edu; Tel.: +1-859-257-2932 or +1-859-266-9737; Fax: +1-859-257-6722

External Editor: Shangyi Zhou

Received: 10 June 2014; in revised form: 18 August 2014 / Accepted: 25 August 2014 /

Published: 29 September 2014

\begin{abstract}
The scholarly world of sustainability science is one that is international and interdisciplinary, but is one, on close reading of research contributions, editoral teams, journal citations, and geographic coverage, that has much unevenness. The focus of this paper is on the cyberspace boundaries between and within fields and disciplines studying sustainability; these boundaries separate knowledge gaps or uneven patterns in sustainability scholarship. I use the volume of hyperlinks on Google Search Engine and Google Scholar to illustrate the nature and extent of the boundaries in cyberspace that exist and also the subject and geographic gaps in the home countries of sustainability journal editors and editorial board members of 69 journals, many which have appeared since 2000 . The results reveal that knowledge boundaries are part of the current nature of sustainability scholarship and that, while there is global coverage in our knowledge of sustainability, as well as sustainability maps and photographs, we know much less about sustainability in countries of the Global South than the Global North. This unevenness extends to the dominance of North America, Europe, and China as leaders in what we know. English-speaking countries also tend to dominate both journal editors and editorial board members, even though countries in the Global South have representation. The volumes of hyperlinks for the sustainability journals associated with both databases are similar with major interdisciplinary journals having the largest numbers. As the field of international sustainability science continues to evolve, it bears observing whether the cyberspace knowledge or boundary gaps will narrow in what is recognized by most science and policy scientists as one of the most important transdisciplinary fields of study in the Global South and North.
\end{abstract}


Keywords: cyberspace knowledge boundaries; sustainability hyperlinks; journals and editors; journal rankings; cross-disciplinary networks; mapping sustainability

"We believe that all this evidence taken together establishes the case for the existence of a young and fast-growing unified scientific practice of sustainability and bodes well for its future success at facing some of humanities greatest scientific and societal challenges." [1] (p. 19545).

"In just over two decades it [sustainability science] has attracted tens of thousands of research authors, practitioners and knowledge users, as well as teachers and students with a geographic, institutional, and disciplinary footprint very different from most science. But its real test of success will be in implementing its knowledge to meet the great environmental and development challenges of this century." [2] (p. 19450).

"These emerging organizational and institutional arrangements will have significant implications for the development of sustainability science, which is chiefly aimed at tackling the challenges of producing, communicating, and integrating different types of knowledge and expertise for the sustainability of the Earth." [3] (p. 124).

\section{Introduction}

The study of sustainability is one that includes the members of many scholarly communities and disciplines in the engineering and natural sciences, but also those in the social and policy sciences [4-7]. Research is also carried out at different scales, from local to regional to international, and with disciplinary and interdisciplinary team members; networking, whether individual scholars or by journal editorial teams, is one of the key features or any interdisciplinary scholarly field [8]. The subject of sustainability, and its many subfields including sustainable development, energy, architecture, tourism, and law, is a relatively new disciplinary, interdisciplinary and transdisciplinary research focus. Buter and van Raan [9] (p. 253) note that sustainability development "is a complex, multifaceted topic that has political, environmental and sociological aspects." Because of the relative newness of the field and its transdisciplinary nature, one would expect there would be some differences or variations in what we currently know, even when examining knowledge from cyberspace sources. Some fields of study and disciplines contribute more; others less with the result that "knowledge boundaries" remain part of the current scholarly landscape. Those subject matter or topical knowledge "gaps" and boundaries in cyberspace would also likely extend to what we know about sustainability research in specific countries and regions, that is, we may know more about sustainable land use, green energy and sustainability policies in some regions more than others.

Cyberspace "knowledge gap" and "knowledge boundary" questions are the central focus of this presentation. We seek to discern the degree or extent of those cyberspace boundaries and also our knowledge about sustainability by looking specifically at several measures or criteria. These include the following: (a) major fields and subfields of sustainability scholarship; (b) sustainability knowledge in broad subject areas, such as engineering, social sciences and humanities; (c) geographic variations 
in sustainability knowledge among countries and in major world regions; (d) variations in the volume of maps and photographs related to sustainability; (e) the home countries of editors and editorial board members of major sustainability journals; and (f) the ranking of sustainability journals.

As we proceed, there are four underlying questions we seek to answer: (1) are there sharp and significant variations in our cyberspace knowledge about sustainability science, that is, ther "boundaries" between major and minor topics? (2) Is our knowledge about sustainability topics uniform or fairly uniform across the planet or are there sharp regional and country differences and boundaries within and between regions? (3) Is there a significance variation in the international representation of editors and editorial board members of sustainability journals or are editorial teams dominated by just a few countries? And (4) are there significant differences in the rankings of professional journals serving the many sustainability scholarly communities? Once we have answers to these "cyberspace knowledge gap" questions in a global context, I poosit some useful follow-up studies.

In this study we are using two search engines: the Google Search Engine, which includes a wide variety of specific subjects and fields and the Google Scholar Search Engine which includes references to scholarly articles, books, chapters, conference proceedings, etc. One would expect there would be some major differences in the volumes of hyperlinks, and "knowledge boundaries", in the two databases. This review is followed by an examination of the following topics: the subject matter of broad fields (engineering, social science, etc.), the regional and geographic variation in subject matter (maps, photos, etc.), the home countries of editors and editorial board members, and, finally, a ranking of major sustainability journals based on the volume of hyperlinks in the two databases.

\section{Literature Review}

This research on cyberspace knowledge and cyberspace boundaries is couched within the broad intellectual framework of studies on information science which scholars explore the impacts of journals, citation counts, and disciplinary and interdisciplinary "knowledge boundaries" in scholarly communities and networks. There are three major literatures that place this research within the existing framework of knowledge science. First are those studies on journal and author bibliometrics, Web of Science and Webometrics [10-21], databases and social science linkages and networks [6,8,15], e-research and university networks [22-25], international networking [26,27], and convergence research areas $[12,13]$. Especially useful are those exploring questions about both disciplinary and interdisciplinary scholarly networks, contributions and emerging trends, mapping domains [28-30]. Second are those studies that use Google Search Engine, including Google Scholar and other commercial search engines [10,19,31-34]. Third are those studies that specifically focus on sustainability science networks and knowledge domains. It is the last group of recent studies that I focus on below.

A number of authors who have investigated the sustainability science field and subfields acknowledge both the recent emergence of this interdisciplinary field and the many different disciplines, including the engineering, social, policy and natural sciences, which are actively contributing to what we know about specific topics, projects or policies [35-42]. Bettencourt and Kaur [1] looked at the authors of sustainability science research articles as well as their countries of origin and the number of citations. Several very specific studies that have appeared in sustainability journals. $[4,42]$ explore the 15 academic clusters (mostly in the natural sciences) conducting research 
on sustainability; agricultural and fisheries were solid clusters with energy still developing. Schoolman et al. [43], in a similar vein, used three "pillars" of the interdisciplinary sustainability science (environmental, economics, and social sciences); economics emerged as the most integrative with the social sciences having the fewest linkages among disciplines. Sherren et al. [44] explored the structure and organization of interdisciplinary academic departments of sustainability in two Australian universities and reported on the pluses and minuses of research collaboration, mentoring, supervision, rewards and training. Buter and Van Raan [9] created an HCKB (Highly Cited Knowledge Base) to identify three major themes in sustainability science disciplinary "pillars" (environment, economic, and sociology); they noted the rich diversity of studies in different disciplines, but also noted that truly transdisciplinary fields are still not fully developed. Yarime et al. [3] also used bibliometric data to explore the amount of international research collaboration on sustainable topics; one of their key findings was that scholars in most countries work on research projects within their own region; scholars from the U.S. and China are exceptions. Most of these studies used similar databases, Web of Science, SCI and SSCI, to graph the increased volume of research articles published on sustainability science in general or in specific fields and disciplines and examine the rankings of journals. Some contributions, it should be noted, included some creative and colorful maps and graphs that show the core and peripheral knowledge communities and convergence research areas [7-9,26,27,45-50], national and international networks [3], increased interdisciplinary networks [6,26], and the countries of authors [35].

\section{Sustainability and Cyberspace: Google Search Engine Results}

Defining sustainability is important in examining research contributions, even if defining the concept is ambiguous [4] (p. 230). In its broadest context, it refers to something that is not completely used up or destroyed, but rather has features or components that can still be used. Frequently, the term refers to natural resources, such as forests or soils, which are not used completely or exhausted, that is, they can be replenished or made renewable for reuse. Various conservation methods have been applied throughout human history to preserve forests, water and agricultural lands for future use. The term sustainability is adopted very widely in academic and policy circles to refer to the recycling of resources and industrial products and also methods to conserve wisely the earth's natural resources (fossil fuels, forests, wind, water, land). One could readily make the case, as various scholars have [51-53], that sustainability and environmental issues are among the most pressing issues facing the disciplinary and interdisciplinary scholarly communities in the sciences and humanities in both the Global North and South.

A central question arises for those interested in looking at the term sustainability in a knowledge-world and also in international arenas. And that is, how can we measure its use? I suggest one fruitful direction is to explore the use of the term using the Google Search Engine database. This information source provides hyperlinks or electronic sources or pieces of information (commonly known as "hits") about a word or word combination we enter into the search engine "box". When we entered the word "sustainable", for example, in January 2014, we discovered there were 62.5 million hyperlinks or sources of information in the Google search engine that contain that word in a title, a report, a table, on a map, etc. There are 227 million hits for the word "sustainability" and 42.4 million for "sustainable development." (For those unfamiliar with this database, the number of hyperlinks changes daily, and 
often even during a day.) These are the number of entries in the English Google Search Engine; there may be more or less in Chinese, Spanish, French, Arabic, and Russian. One might think of other electronic sources or databases (Chinese- Baidu or Navre- Korean) that would also provide some quantifiable measure of "sustainable" and "sustainability". We could also consider books in a library or articles and book reviews in scholarly journals, as well as articles in magazines, newspapers and conference proceedings. My view is that in an electronic information world, electronic bits or bytes of information probably represent the best sources to learn how much is "out there" about a given subject. And it is a legitimate context within which to study intersecting human/environment relations, including sustainability in disciplinary and interdisciplinary frameworks.

A more specific inquiry into the nature of these electronic scholarly worlds of sustainability can be obtained by utilizing the Google databases, and, more specifically by examining the word "sustainable" alongside related terms. For example, one can enter into the Google search engine "sustainable + agriculture" or "sustainable + forestry" or "sustainable + development" or "sustainable + tourism." Examples of the volume of hyperlinks associated with different combinations using the Google Search Engine are shown in Figures 1 and 2. The first map used the Google Search Engine, which provides the number of hyperlinks for each word or phrase inserted into the "search box." For the second, I entered the same phrases in the Google Scholar "search box." The latter database should provide different volumes because these references relate to entries in scholarly publications.

Figure 1 shows the word combinations associated with planning, architecture, law, religion, politics, medicine, energy, recycling, transportation, tourism, the military and education. The largest number of references relate to education, policy, health and energy-200-350 million hyperlinks in each combination. There are more than 50 million for these subjects: architecture, land use, climate change, housing, the internet and agriculture. There are more than 25 million for preservation, gender, recycling, waste management and product design; and fewer than 8 million for religion, aquaculture, logistics and GIS. The figure confirms a central point of this paper; viz., that the term "sustainable" is not only multidisciplinary, but also interdisciplinary and transdisciplinary, not just with a handful of topics, but a wide range of topics studied in the social, behavioral, policy and natural sciences.

There were many fewer entries in Google Scholar for the same word combinations: sustainability + land use, gender, tourism, health, development, etc. The number of hyperlinks ranged from 1.97 million for land use to only 49,000 for "sustainability + aquaculture". The total number of hyperlinks for the 52 categories was 40.1 million. The entries are divided into four categories: a core group (over 1.3 million), semiperiphery (700,000-1.29 million), periphery $(200,000-699,000)$ and a deep periphery (less than 200,000 hyperlinks (Figure 2). The numbers of combinations are roughly the same in each of the four categories. The dozen entries in the "core" had 46 percent of the total, but only seven percent in the periphery and three percent in the deep periphery. 
Figure 1. Volume of entries in the google search engine for "sustainability + term" (for example, sustainability + policy) (9 January 2014).

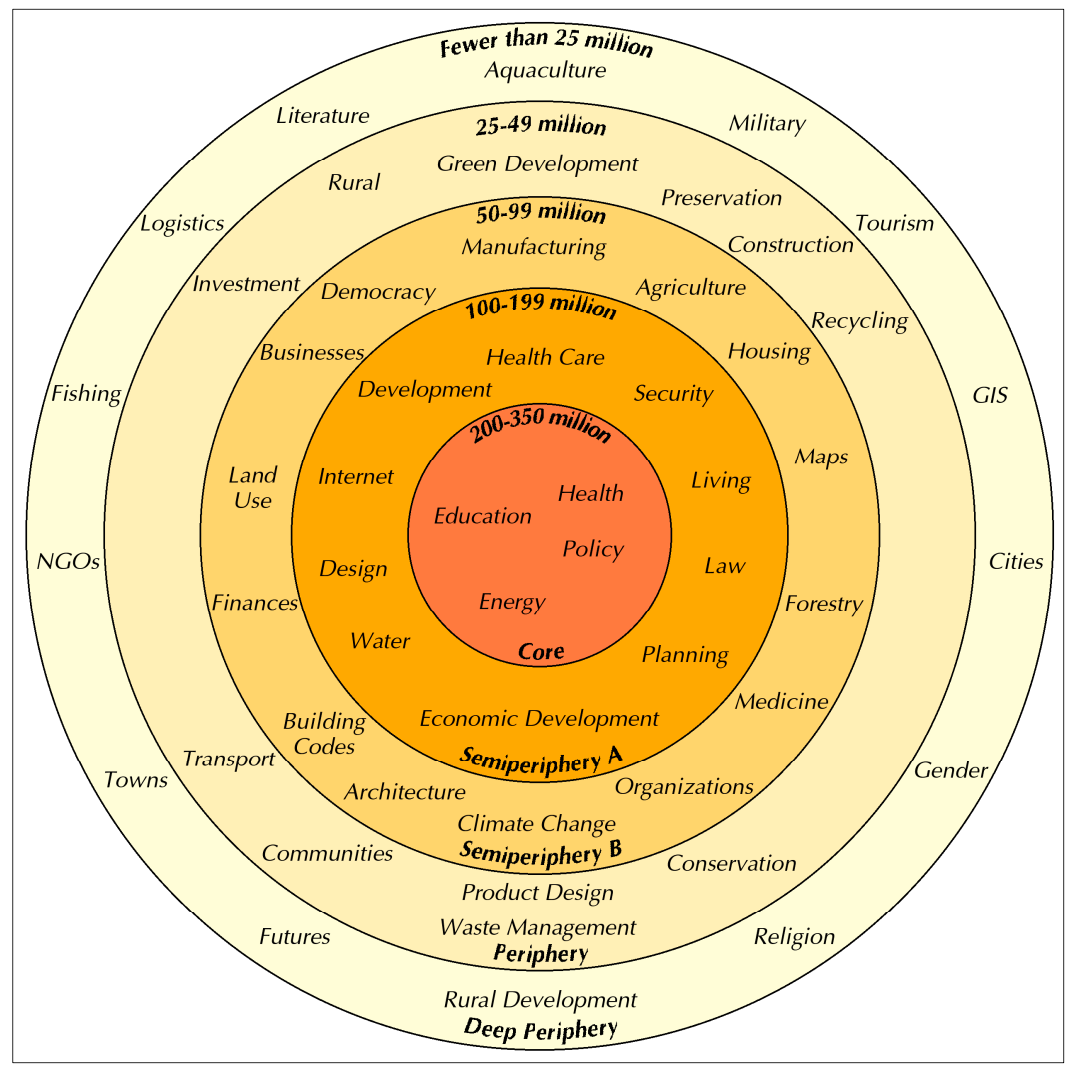

Figure 2. Volume of entries in google scholar for "sustainability + term" (for example, sustainability + policy) (9 January 2014).

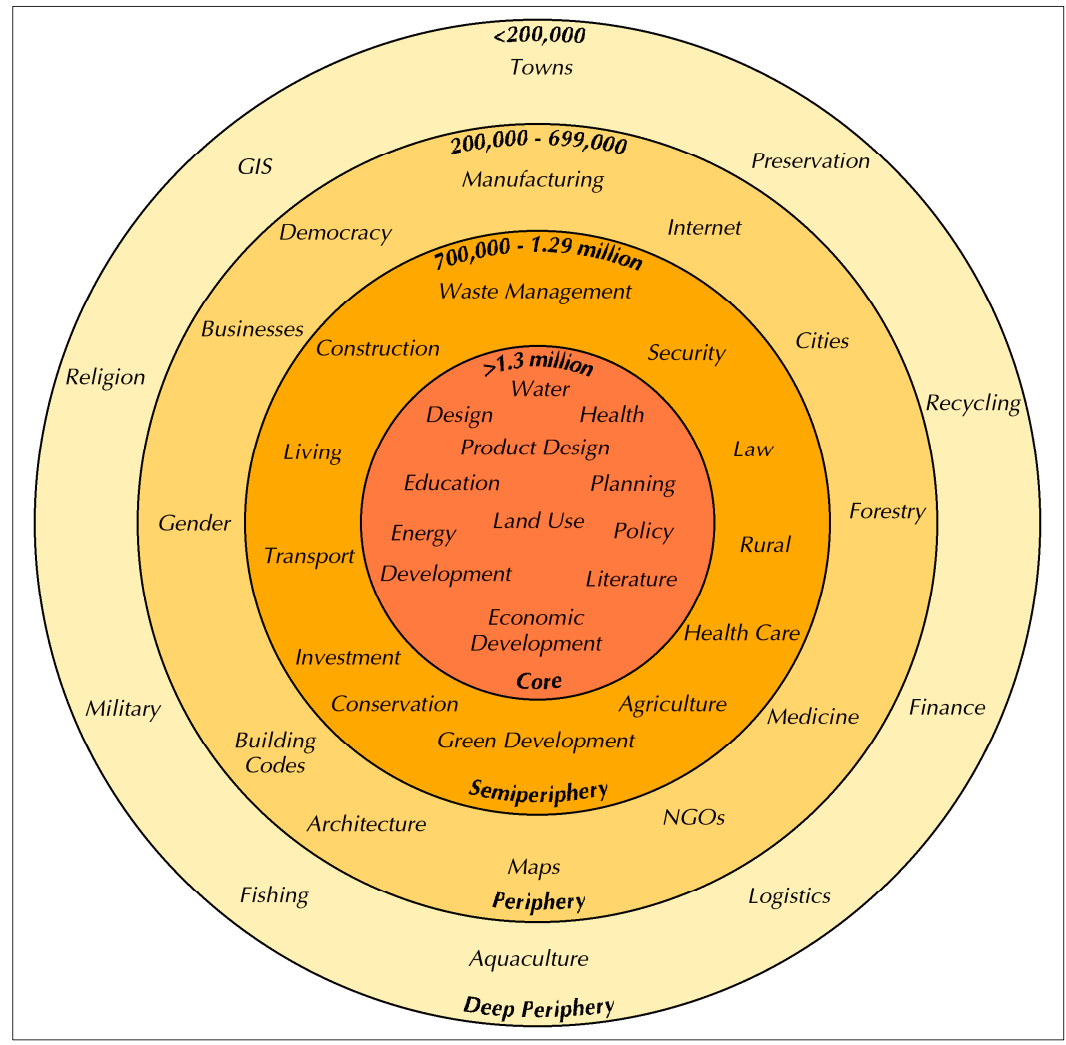




\section{Disciplinary Knowledge about Sustainability and Sustainable Development}

The gaps in subject matter categories also extend to broad fields of scholarly inquiry which contribute to subject matter related to sustainability and sustainable development; I again used Google and Google Scholar. In both searches I entered not only broad terms, such as sustainability + engineering, sustainability + social sciences, and sustainability + natural/earth sciences, but also major subject matter areas under each broad head. Under the social science heading I entered specific disciplines, such as anthropology, sociology, political science, geography, economics and psychology and under engineering I included civil, chemical, and mechanical engineering. I did the same for the term sustainable development for the generic Google Search Engine and for Google Scholar as I wished to find out if there were any differences in the volumes of information in these two databases and for these broad fields of study.

The results of these broad searches are shown in Figure 3. Six broad subject categories are shown.

Figure 3. Hyperlinks for google search engine (left side) and google scholar (right side).
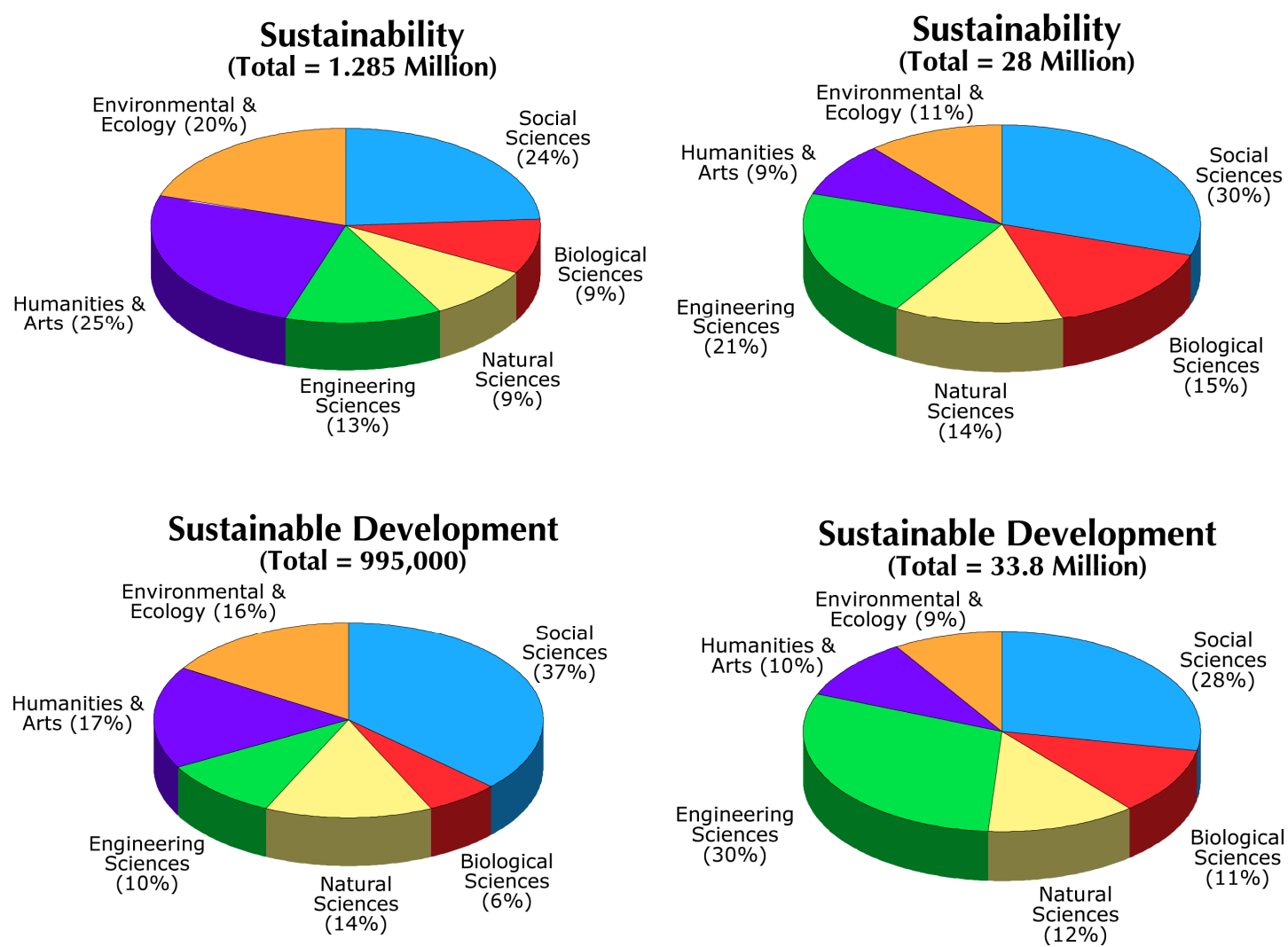

Using the Google Search Engine there were 1.28 million hyperlinks for sustainability and 995,000 for sustainable development. The numbers were, as expected, much less for each heading using Google Scholar: 28 million for sustainability and 33.8 million for sustainable development. The social sciences tended to dominate the six categories, but if one combined the three science and engineering categories, there were more Google entries, especially in the Google Scholar database. The engineering sciences and social sciences dominated the Google Scholar database, far outpacing the number of studies in the humanities and arts, a finding similar to the hyperlink volumes shown in Figures 1 and 2. The humanities, at least at present, are not contributing significantly to sustainability research. 


\section{Sustainability Journals, Editors and Editorial Boards}

Another perspective on sustainability knowledge is obtained by looking at professional journals with the word "sustainable" in the title. One would expect these journals to have both disciplinary and interdisciplinary authors and co-authors, book reviewers, as well as networks of editors and editorial board members. I identified 69 journals published in English with the word "sustainable" or "sustainability" in the title. In this analysis, I am using only English-language journals about sustainability, realizing, as stated above, that there are scholarly journals published in German, French, Russian, Chinese, Arabic, Italian, Dutch, Portuguese, and Japanese. I use English as it is the leading language for scholarly communication and also for electronic journal publishing. Scholars around the world today need to be conversant in and comfortable with the English language if they wish to become integrated into global scientific communities.

Examples of journals included in this study are: International Journal of Sustainable Economy, International Journal of Sustainability, Journal of Sustainable Tourism, Journal of Sustainable Development in Africa, Sustainable Construction Engineering and Technology, and International Journal of Sustainable Development and Planning (Box 1). A detailed examination of the contents of recent issues of these and other journals would underscore the international, interdisciplinary, transdisciplinary and cross-disciplinary content of this subject area. For example, there are many disciplines, fields and subfields interested in sustainability and law, chemistry, agriculture, forestry, education, engineering, architecture, water, economies, and also manufacturing and real estate. More than half of the journals have appeared since 2000 and a number in 2012 and 2013. Examples of new journals include: International Journal for Sustainable Materials and Structural Systems, Journal of Engineering for Sustainable Community Development and International Journal of Sustainable Land Use and Urban Planning. This observation in itself illustrates the growing importance of this emerging and engaging interdisciplinary field of study. The number of journals publishing articles on these topics would increase if one looked at journals with the words "environment" or "ecology" in the title or subtitle.

Box 1. Titles of 69 English-language sustainability journals. (Sources: websites, May 2014).

General: International Journal of Sustainability; Sustainability; Sustainability Science

Agriculture: International Journal of Agricultural Sustainability; International Journal of Sustainable

Agriculture; International Journal of Sustainability Agricultural Management and Informatics; Journal of Agricultural Biotechnology and Sustainable Development; Agroecology and Sustainable Food Systems: Journal of Sustainable Agriculture: Journal of Developments in Sustainable Agriculture Architecture: Journal of Creative Sustainable Architecture and Built Environment; International Journal of Sustainable Built Environment; International Journal of Sustainable Design; International Journal of Sustainable Tropical Design Research and Practice

Chemistry: ACS Sustainable Chemistry \& Engineering

Communications: International Journal of Sustainability Communication

Construction: International Journal for Sustainable Construction Engineering and Technology;

International Journal of Sustainable Building Technology and Urban Development 
Box 1. Cont.

Development: Environmental Management and Sustainable Development; Environment, Development and Sustainability; International Journal of Environment and Sustainable Development; International Journal of Sustainable Development \& World Ecology; International Journal of Sustainable Development; Journal of Sustainable Development

Economics: Journal of Economics and Sustainable Development; International Journal of Sustainable Economy

Education: Journal of Education for Sustainable Development; International Journal of Sustainability in Higher Education

Energy: Energy for Sustainable Development; Energy, Sustainability and Society: Journal of Sustainable Energy and Environment; Journal of Renewable and Sustainable Energy; IEEE Transactions on Sustainable Energy; International Journal of Sustainable Energy; Renewable and Sustainable Energy Reviews; Journal of Sustainable Energy and Environment; International Journal of Sustainable Energy and Environment

Engineering: Journal of Engineering for Sustainable Community Development: International Journal of Sustainable Engineering; International Journal of Sustainable Materials and Structural Systems

Forestry: Journal of Sustainable Forestry

Information: Journal for a Global Sustainable Information Society; International Journal of Innovation and Sustainable Development

Law: McGill International Journal of Sustainable Development Law and Policy; Sustainable Development Law and Policy

Management: International Journal of Sustainable Strategic Management; International Journal of Technology Management and Sustainable Development

Manufacturing: International Journal for Sustainable Product Design; International Journal of Manufacturing and Renewable Energy

Medicine and Health: International Journal of Public Health and Sustainable Development; Symbiosis: Journal of Ecologically Sustainable Medicine

Planning: Sustainable Development and Planning

Regional: African Journal of Economic and Sustainable Development; American-Eurasian Journal of Sustainable Agriculture; Asia Pacific Journal of Environmental Ecology and Sustainable Development; European Journal of Sustainable Development; Journal of Himalayan Ecology and Sustainable Development; Journal of Sustainable Development in Africa; Latin American Journal of Management for Sustainable Development

Religion: Mother Pelican: A Journal of Solidarity and Sustainability

Security: International Journal of Sustainable Future for Human Security

Society: International Journal of Social Ecology and Sustainable Development; International Journal of Sustainable Society

Tourism: Journal of Sustainable Tourism

Transport: International Journal of Sustainable Transportation; Journal of Logistics \& Sustainable Transport

Urban: International Journal for Sustainable Land Use and Urban Planning; International Journal of Urban Sustainable Development; Sustainable Cities and Society

Water: International Journal of Sustainable Water and Environmental Systems

Two additional perspectives on international scholarship and scholarly communities are obtained by looking at the gatekeepers or editors and editorial boards of professional journals. These are key 
individuals in what members of professional societies, students and policy makers read to keep abreast of the latest developments in their disciplines and related fields and at local, regional and global scales. Editors and associate editors make the final decisions regarding the acceptance and publication of manuscripts; editorial board members aid in the process of making recommendations on manuscripts or encourage authors to submit manuscripts for possible publication. Where the editors reside, that is, in what countries, is important in establishing their own professional networks with professional organizations, board members, reviewers and with authors themselves.

In looking at knowledge gap questions there were three questions. First, what are the leading countries where editors and editorial members reside? For example, are they from the Global North or developed world? Second, do English speaking countries dominate the editorships and editorial boards of these journals? Third, what world regions are disadvantaged or marginalized by having only a few editors and board members associated with these journals? Answers to these questions will provide evidence of a gap exist.

I obtain the above information from the web pages of the 69 journals listed in Box 1. Often these web pages are developed by publishers who list the most recent journal articles, the names and countries of origin of editors and board members, who form part of the invisible networks of scholarly communities. These web pages also provide addresses (universities, government offices, about board members) and information for those submitting manuscripts. The journals listed in Box 1 run the gamut from publishing articles on sustainability for broad scholarly communities to those focusing on development, agriculture, architecture, engineering, manufacturing, management, security and tourism and those which publish articles about sustainable development issues in Latin America, Africa, Europe, and Asia. Some journals have a single editor or editor-in-chief while others have associate editors and regional editors. Almost all journals have editorial board members; some have less than a dozen, others 30, and a few exceeding 90. I counted 219 editors and associate editors for the 69 journals. Some journals also have regional editors and editors handling specific subject matter. The editors came from 44 different countries (Figure 4).

The United States, perhaps not unexpectedly, has 70 (33 percent) of the editors, which was more than the next two countries (the United Kingdom and China) combined. Twenty countries had more than two editors and 24 had one. Editors came from all continents, which reflects well on the international scholarly nature of subject matter related to sustainability. Examples include Energy for Sustainable Development (editor from Argentina), Sustainability (editors from the United States, China, Ireland and Switzerland), International Journal of Sustainable Materials and Structural Systems (editor-in-chief from China and associate editors from the United States, Switzerland and China), International Journal of Sustainable Agricultural Management and Informatics (editor from Greece and associate editors from Spain, Italy, Germany and Greece), International Journal of Sustainable Economy (Slovenia), International Journal for Sustainable Built Environment (Qatar), International Journal of Sustainable Agricultural Management and Informatics (Greece), International Journal for Sustainable Building Technology and Urban Development (South Korea), and Journal of Sustainable Tourism (United Kingdom, New Zealand and China). 
Figure 4. Home countries claimed by editors of sustainable development journals (7 January 2014).

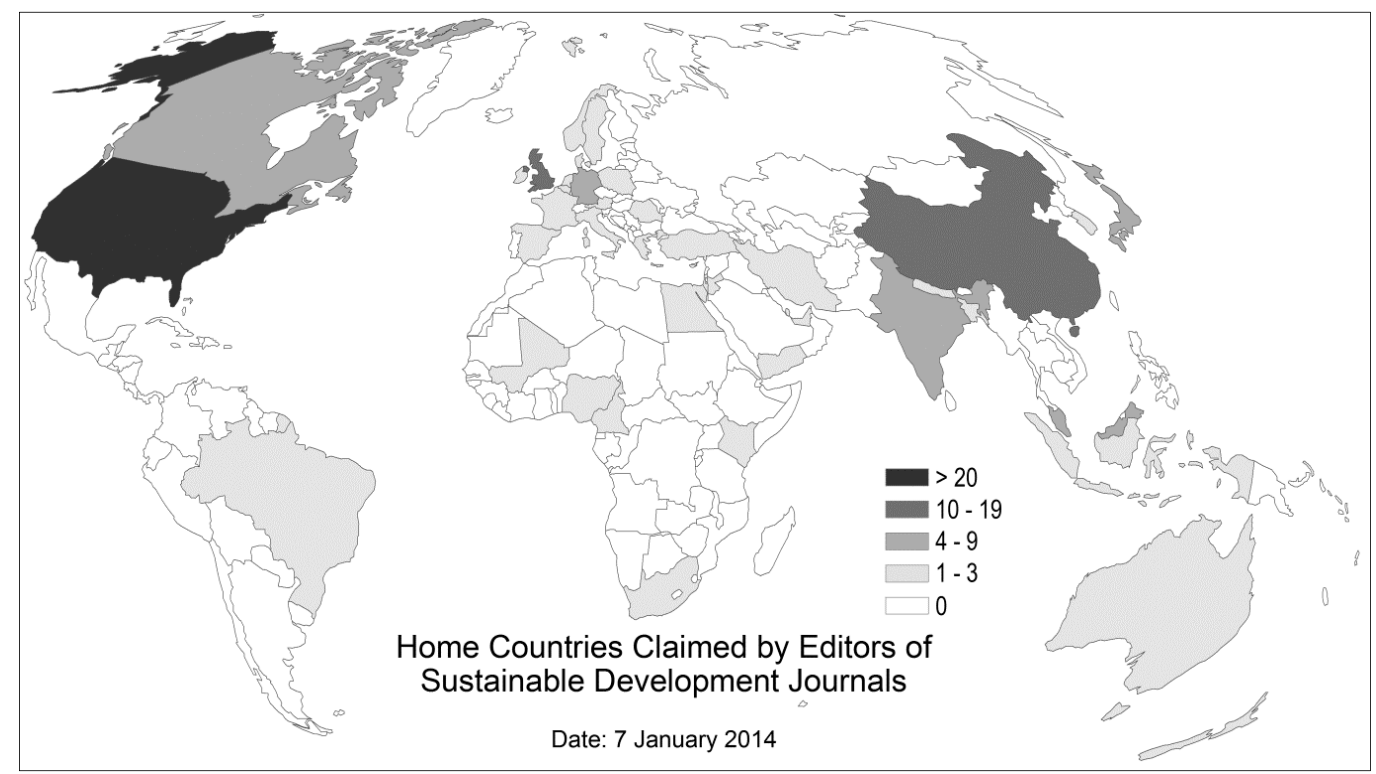

The distribution of editorial board members has some striking similarities to the map of editors, especially in the case of the United States, United Kingdom and China (Figure 5). Of the 1639 board members on the 69 English language journals, 455 (28 percent) are from the United States alone. This exceeds the combined total of the next five leading countries: United Kingdom, China, Germany, Australia and Japan. Altogether, 84 countries have scholars on the editorial board of at least one journal focusing on sustainability; 30 countries have one or two members. All continents have scholars on one or more editorial boards: 32 from European countries, 22 from Africa and the Middle East and 10 from Latin America. Very few have board members from Africa, South and East Asia (except China and Japan), and Latin America.

Figure 5. Home countries claimed by editorial board members of sustainable development journals (7 January 2014).

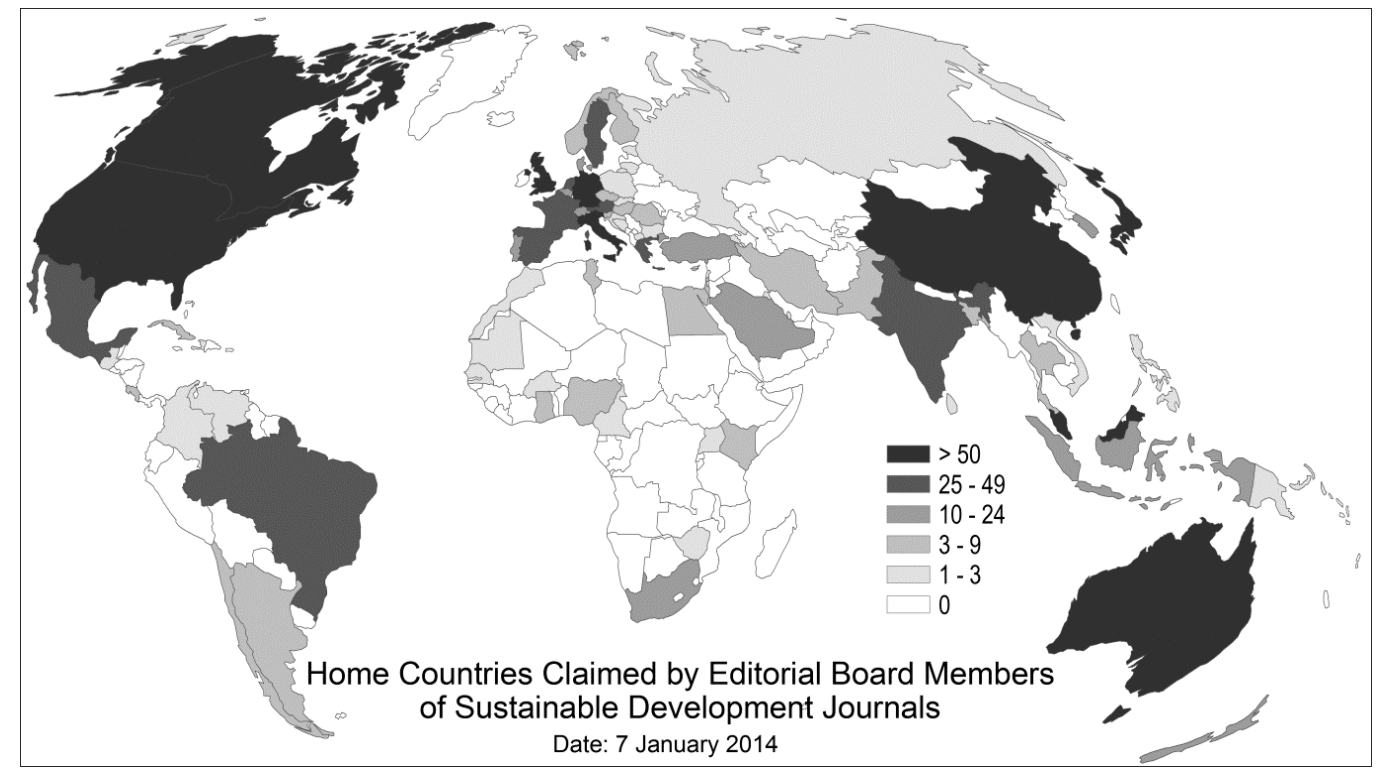


Some journals have large editorial boards; nine countries have more than 50 members and another 16 have 25-49 members. Those with the largest boards are the International Journal of Sustainable Society (100 members), Journal for a Global Sustainable information Economy (94), Journal of Sustainable Agriculture (91), Agroecology in Sustainable Food Systems (89), Sustainability (79) and Journal of Agricultural Biotechnology and Sustainable Development (56). Other journals have only a few board members. These journals have only 10 members: International Journal of Sustainable Development and World Ecology, International Journal of Sustainability and International Journal of Sustainable Future for Human Security.

Some journals have board members from many countries and others very few (Figure 6). The Journal of Global Sustainability Society has board members from 26 different countries, the Journal of Agricultural Biotechnology from 24, the International Journal of Sustainable Development from 22, Sustainable Development and Planning from 21, the Journal of Sustainable Agriculture from 20, the International Journal for Sustainable Agricultural Management and Informatics from 19 and the International Journal of Urban Sustainable Development also from 19 and the International Journal of Sustainable Energy and Environment from 18 countries. Examples of journals with board members from few countries are the International Journal of Technology Management and Sustainable Development (nine countries with one-third of the 19 members from the United Kingdom), International Journal of Sustainable Communication (six countries with most from Germany), International Journal of Strategic Management (six countries and two-thirds coming from the United States), the Journal of Sustainable Forestry (five countries and most from the United States), the International Journal of Sustainability (four and most from China), the International Journal of Sustainable Economy (half from Slovenia and the United States) and the International Journal of Sustainable Future for Human Security (four countries with over half coming from Japan). Note the paucity of board members from the Global South.

Examples of journals with an in-between number of members from different countries are the International Journal for Sustainable Technology and Urban Development [17], International Journal of Sustainable Product Design (16 countries), Journal of Sustainable Engineering also [16] and two regional journals, American-Eurasian Journal of Sustainable Agriculture [16] and Latin American Journal of Management for Sustainable Development [15]. It is worth noting that the regional journals often include board members who reside outside the focus of the journal. For example, Latin American Journal of Management for Sustainable Development has board members in China, Germany, Turkey and the Netherlands, the America-Eurasian Journal of Sustainable Agriculture has members in Italy, Bosnia-Herzegovina, Nigeria, Pakistan and the United Kingdom and the African Journal of Economics and Sustainable Development has members living in Czech Republic, Haiti and the United States and Advisory Board members from Romania and the United Kingdom. 
Figure 6. Home countries claimed by editorial board members of various journals (7 January 2014).
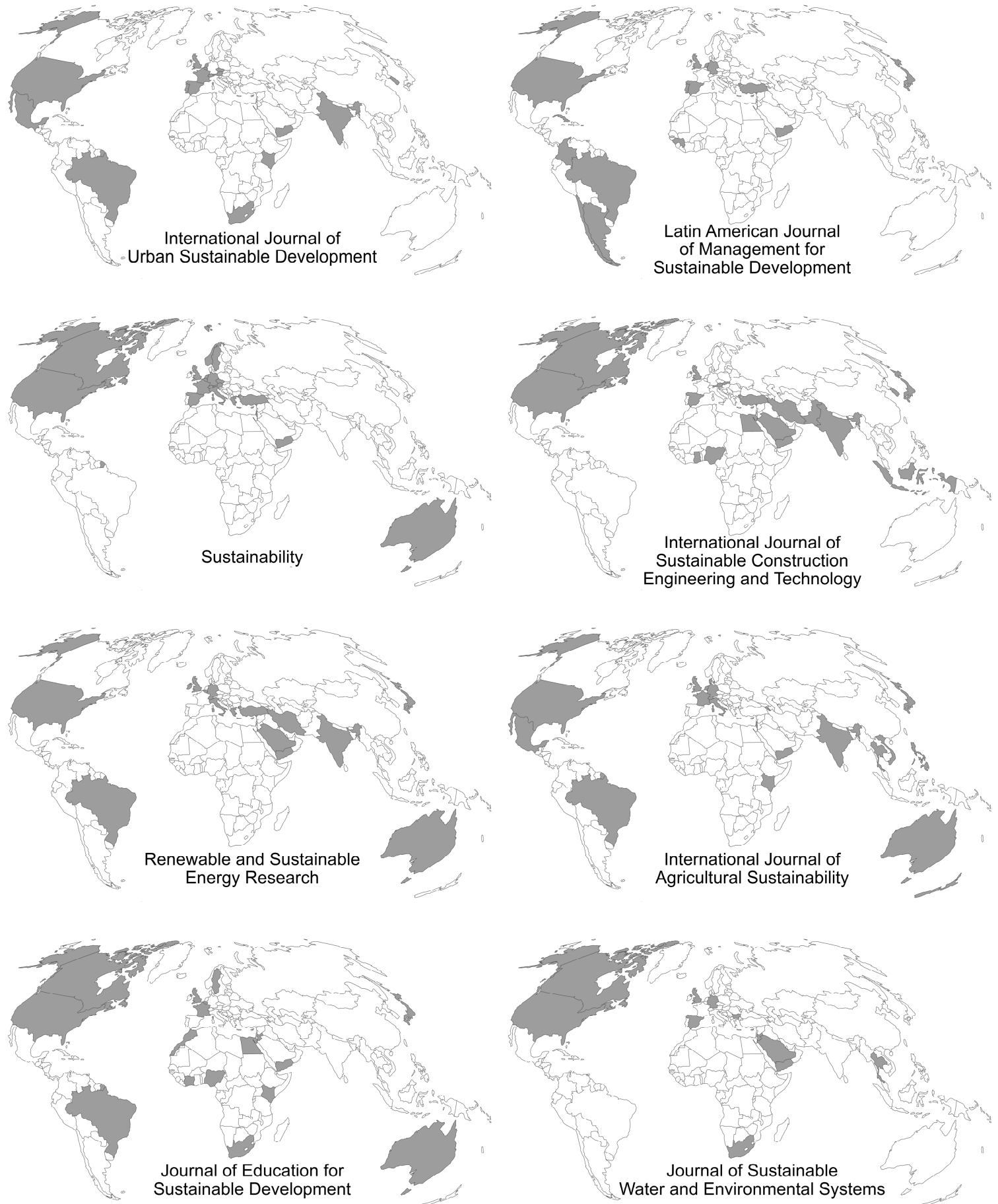

\section{Ranking of Journals Using Volume of Hyperlinks}

A number of scholars have used journal citations and rankings to identify the leading outlets for research in various fields $[2,5,9,25,26,32]$. The Web of Science, Webometrics and the impact factors have been used. While these databases have merit, they have one major drawback when examining the contemporary scholarly impacts of currently published sustainability journals and that is that few have been published a sufficient number of years to have a citation ranking. This point is 
acknowledged in the Appropredia website which states: "New journals will not have an impact factor. Sustainability/Appropriate Technology is a new and interdisciplinary field and impacts factors are of lesser value to it than a conventional field like medicine" [28]. As noted above, many of the 69 sustainability journals used in this study appeared only in the past five years and some more recently than that. Only about one-third have any impact factor. The lack of any sustainable and comparable record of citing articles in major journals suggests that another parameter needs to be considered. I used the volume of hyperlinks for each of the 69 journals using the Google Search Engine and Google Scholar databases. As imperfect as these databases are, they provide some comparable data for all journals considered in this study.

I entered in the search bar the word "journal:" followed by the name of the journal. For example, "Journal: Environmental Management and Sustainable Development", "Journal: Journal of Sustainable Tourism", etc. I repeated this operation for the remaining journals using the databases. The former, as noted above, is a more generic database while the latter provides citations (books, articles, monographs, reports, etc.) from scholarly journals. I considered the volume of hyperlinks as an indication of the importance of each journal in the knowledge worlds of sustainability.

The results of these searches revealed significant differences or knowledge gaps in the number (or volume) of references or hyperlinks for each journal. The Google Search Engine especially reflected major differences in the volumes of hyperlinks (Box 2). The journals with the most hyperlinks in the Google Search Engine are shown in Box 3.

Box 2. Number of hyperlinks for major sustainability journals: google search engine.

Over 50 million (7): Sustainability Science; International Journal of Manufacturing and Renewable Energy; International Journal of Sustainable Product Design; Journal of Sustainable Development; International Journal of Sustainable Strategic Management; Journal of Economics and Sustainable Development; International Journal of Sustainable Development; Journal of Education for Sustainable Development

25-49.9 million (11): Energy for Sustainable Development; Journal of Sustainable Agriculture; International Journal of Sustainable Engineering; International Journal of Environment and Sustainable Development; International Journal of Technology Management and Sustainable Development; Environmental Management and Sustainable Development; International Journal of Public Health and Sustainable Development; Journal for a Global Sustainable Information Economy; Journal of Sustainable Development in Africa; Sustainability; International Journal of Innovation and Sustainable Development 10-24.9 million (13): Sustainable Development Law and Policy; Sustainable Development and Planning; Journal of Sustainable Forestry; International Journal of Sustainability in Higher Education; International Journal of Sustainable Transportation; International Journal of Agricultural Sustainability; Environmental Sustainability and Society; International Journal of Sustainable Agriculture; International Journal of Urban Sustainable Development; Latin American Journal of Management for Sustainable Development; Environment, Development and Sustainability; Journal of Engineering for Sustainable Community Development: Journal of Sustainable Tourism 
Box 2. Cont.

1-9.9 million (30): International Journal of Sustainability Communication; Energy, Sustainability and Society; International Journal of Sustainability; Symbiosis: Journal of Ecologically Sustainable Medicine; European Journal of Sustainable Development; International Journal of Sustainable Society; International Journal of Sustainable Economy; International Journal of Sustainable Energy and Environment; AES Sustainable Chemistry \& Engineering; International Journal of Sustainable Development \& World Ecology; International Journal of Sustainable Management; International Journal of Sustainable Engineering; African Journal of Economic and Sustainable Strategic Development; Journal of Creative Sustainable Architecture and Built Environment; International Journal of Sustainable Materials and Structural Systems; International Journal of Sustainable Water and Environmental Systems; International Journal of Sustainable Future for Human Security; International Journal of Sustainable Design; International Journal of Sustainable Building Technology and Urban Development; Renewable and Sustainable Energy Reviews; International Journal of Sustainable Construction Engineering and Technology; International Journal of Sustainable Land Use and Urban Planning; International Journal of Sustainable Built Environment; Journal of Renewable and Sustainable Energy; International Journal of Social Ecology and Sustainable Development; International Journal of Sustainable Tropical Design Research and Practice; Sustainable Cities and Society; Journal of Agricultural Biotechnology and Sustainable Development; Journal of Logistics \& Sustainable Transportation; Journal of Developments in Sustainable Agriculture

Fewer than 1 million (8): International Journal of Sustainable Agricultural Management and Informatics; Mother Pelican: Journal of Solidarity and Sustainability; Asia Pacific Journal of Environmental Ecology and Sustainable Development; Journal of Himalayan Ecology and Sustainable Development; McGill International Journal for Sustainable Development: Law and Policy; IEEE Transactions on Sustainable Energy; American-Eurasian Journal of Sustainable Agriculture; Agroecology and Sustainable Food Systems; Sustainability Science (166 million), International Journal of Manufacturing and Renewable Energy (96.5 million), Journal of Sustainable Development (93.8 million), Journal of Education for Sustainable Development (84.6 million), Energy for Sustainable Development (73 million), International Journal for Sustainable Management (62.7 million) and Journal of Economics and Sustainable Development (61.2 million). These 7 journals were the only ones with more than 50 million hyperlinks. Another 11 journals had from 25-49 million hyperlinks in the Google Search Engine; these included: International Journal of Global Sustainable Development. Energy for Sustainable Development, Journal of Energy and Sustainable Development, Journal of Sustainable Agriculture, International Journal of Environment and Sustainable Development, International Journal of Public Health and Sustainable Development, Environmental Management and Sustainability, International Journal of Sustainable Society, Journal for Global Sustainability and Information Economy, Journal of Sustainable Development in Africa, Sustainability and International Journal of Innovation and Sustainable Development.

Another 13 journals had between 10-24.9 million hyperlinks, another 30 between 1.0 million and 9.9 million and 8 less than 1 million hyperlinks. Examples of journals with middle values (8-11 million) included those on a wide range of topics, including: International Journal of Sustainable Communications, Latin American Journal of Manufacturing and Sustainable Development, Economic Development and Sustainability and Energy, Sustainability and Society. These journals had between 1-2 million hyperlinks: International Journal of Sustainable Tropical Design, Journal of Logistics and Sustainable Transport, International Journal for Sustainable Strategic Management, and Journal of Agricultural, biotechnology and Sustainable Development. Eight journals had fewer than 1 million hyperlinks; these 6 had from 100,000-999,999: International Journal of Sustainable Agricultural Management and Informatics, Mother Pelican: A Journal of Sustainable Human Development, Asia Pacific Journal of Environmental Ecology and Sustainability, Journal of Himalayan Ecology and Sustainable Development, McGill International Journal for Sustainable Development and IEEE Transactions and Sustainable Engineering and these 2 had fewer than 100,000 hyperlinks: American-Eurasian Journal of Sustainable Agriculture and Agroecology and Sustainable Food Systems. 
Box 3. Number of hyperlinks for major sustainability journals: google scholar. (Sources: google search engine and google scholar 8-9 May 2014).

Over 2.5 million (5): Sustainability Science; Journal of Engineering for Sustainable Community Development; Renewable and Sustainable Energy Reviews; Journal of Sustainable Development; International Journal for Sustainable Construction Engineering and Technology

1-2.49 million (35): Journal of Sustainable Energy and Environment; International Journal of Sustainable Economy; International Journal of Sustainable Engineering; International Journal of Sustainable Design; International Journal of Sustainability; Energy for Sustainable Development; International Journal of Sustainable Product Design; Journal of Education for Sustainable Development; International Journal of Sustainable Development; Journal of Sustainable Energy and Environment; International Journal of Sustainable Society; International Journal of Environment and Sustainable Development; International Journal for Sustainability Strategic Management; European Journal of Sustainable Development; International Journal of Sustainable Communication; Journal of Economics and Sustainable Development; Environmental Management and

Sustainable Development; Sustainable Development and Planning; International Journal of Sustainable Energy and Environment; Journal of Sustainable Agriculture; International Journal of Technology Management and Sustainable Development; Sustainability; International Journal of Sustainable Transportation; International Journal of Sustainable Agriculture; Journal for a Global Sustainable Information Society; Sustainable Development Law and Policy; International Journal of Innovation and Sustainable Development; International Journal for Sustainable Built Environment; International Journal of Public Health and Sustainable Development; International Journal of Urban Sustainable Development; Journal of Sustainable Development in Africa; Journal of Sustainable Forestry; International Journal of Sustainable Water and Environmental Systems; Energy, Sustainability and Society; International Journal of Agricultural Sustainability

100,000-999,999 (17): International Journal of Sustainable Land Use and Urban Planning; AES Sustainable Chemistry \& Engineering; Sustainable Cities and Society; International Journal of Sustainability in Higher Education; International Journal of Social Ecology and Sustainable Development; International Journal of Sustainable Future for Human Security; International Journal for Sustainable Building Technology and Urban Development; Journal of Developments in Sustainable Agriculture; Journal of Sustainable Tourism; International Journal of Sustainable Development \& World Ecology; Renewable and Sustainable Energy Reviews; African Journal of Economic and Sustainable Development; Journal of Renewable and Sustainable Energy; International Journal of Sustainable Tropical Design Research and Practice; International Journal of Sustainable Materials and Structural Systems: International Journal of Manufacturing and Renewable Energy; Latin American Journal of Management and Sustainable Development

Fewer than 100,000 (12): Journal of Creative Sustainable Architecture and Built Environment; Journal of Logistics \& Sustainable Transport; IEEE Transactions on Sustainable Energy; McGill International Journal for Sustainable Development: Law and Policy; Agroecology and Sustainable Food Systems; Journal of Himalayan Ecology and Sustainable Development; International Journal of Sustainable Agricultural Management and Informatics; Journal of Agricultural Biotechnology and Sustainable Development; Asia Pacific Journal of Environmental Ecology and Sustainable Development; AmericanEurasian Journal of Sustainable Agriculture; Mother Pelican: A Journal of Solidarity and Sustainability; Symbiosis: Journal of Ecologically Sustainable Medicine 
These volumes in Google Scholar ranged from 2.6 million to fewer than 500. There were five journals with more than 2.5 million hyperlinks: Sustainable Science, International Journal for Sustainable Construction Engineering and Technology, Journal of Energy for Sustainable Development, Journal of Engineering for Sustainable Development and Journal of Sustainable Development. And there were 35 journals with 1.0-2.49 million hyperlinks and 17 from 100,000 to 999,000 hyperlinks. Examples of journals with about one million hyperlinks include: International Journal of Agricultural Sustainability, International Journal of Urban Sustainable Development, International Journal of Sustainable Product Design, International Journal of Sustainable Water and Environmental System, Latin American Journal of Manufacturing and Sustainable Developments and Journal of Sustainable Forestry. Twelve journals had fewer than 100,000 hyperlinks: many of these were also those with the fewest entries in the Google search.

When the rankings (hyperlink volumes) of the 69 journals using the Google Search Engine and Google Scholar are compared, there are some distinct differences. The journals with the most hyperlinks tended to have the most in both databases. Examples include: Sustainability Science, Journal of Sustainable Development and Journal of Education for Sustainable Development. The same holds true for those with the fewest entries in both databases; examples include: American-Eurasian Journal of Sustainable Agriculture, Agroecology and Sustainable Food Systems, Journal of Himalayan Ecology and Sustainable Development and IEEE Transactions on Sustainable Engineering. Examples of journals in the middle of both rankings include: Economic Development and Sustainability and International Journal of Technology Management and Sustainable Development. However, there were some differences. For example, four journals that had higher rankings in the Google search engine than in the Google Scholar are: International Journal of Manufacturing and Renewable Energy, Journal of Global Sustainable Society, and Symbiosis: Journal of Ecologically Sustainable Medicine and Journal of Sustainable Tourism. On the other hand these three journals had much higher rankings on Google Scholar than in the Google Search Engine: Journal of Engineering for Sustainable Development, International Journal for Sustainable Construction and International Journal of Sustainable Product Design. There are clearly some significant gaps between the highly ranked sustainable journals and those that publish articles for Global South audiences.

\section{Mapping the Global Cyberspace Geographies of Sustainability}

The two questions I raise in this section are: (1) how can one "map" sustainability at a global scale and (2) what measures or criteria can be used? To answer these questions, I use the volume or number of hyperlinks about sustainability measures in the Google Search Engine for the nearly 200 countries on the world political map. If there are many of these electronic information sources or cyberspace references associated with a country, then sustainability is considered more important to the scholarly communities than if there were only a few. Few hyperlinks may be because "sustainable" issues are not that important in the government, planning and education agendas or that important for members of scholarly communities. These data were collected the first week of January 2014 and used in preparing the maps described below.

For the first map, I entered the words "sustainable development" for each country, for example "sustainable development + Belgium", "sustainable development + Chile", and "sustainable 
development + Japan". These paired hyperlinks provide a database from which one could look at sustainable development at global levels, major regions and countries. I conducted the same "paired" terms for every country using "sustainable development + Belgium + maps", "sustainable development + Chile + maps", etc. The same procedure was used to obtain the volume of photographs about sustainable development for each country, for example, "sustainable development + "Belgium + photos", "sustainable development + Chile + photos", etc. My thinking was that using and mapping these data would provide useful and comparable measures of sustainable development at global, regional and country scales of sustainable development.

There were nearly 2 billion hyperlinks for "sustainable development" and all 193 countries (Figure 7). The leading countries were the U.S. with 89 million, China 85 million, Canada 68 million, South Africa 60 million and Australia 58 million. These six countries had 17 percent of all hyperlinks. Another 26 countries had from 20 to 49 million hyperlinks. These included countries in the Global South and Global North. For example, Brazil and Mexico both had about 40 million; Italy and Russia about 30 million, Spain and Indonesia (about 28 million) and Switzerland and Nigeria (about 20 million each). Thirty-six countries had between 10 to 19 million hyperlinks related to sustainable development and 27 had between 5 and 9 million. There were 101 countries had fewer than 5 million hyperlinks and 8 had less than 1 million. The fewest hyperlinks were for Nauru $(800,000)$, St. Kitts and Nevis (720,000), East Timor (580,000), and the Federated States of Micronesia $(300,000)$. The map reveals variation not only within Europe (with fewer references in eastern and southeastern Europe), but also within South America and the Middle East and North Africa. The regions with the fewest hyperlinks were the Pacific Basin followed by Sub-Saharan Africa.

Figure 7. "Sustainable development" number of hyperlinks (English) (google search engine, 2014).

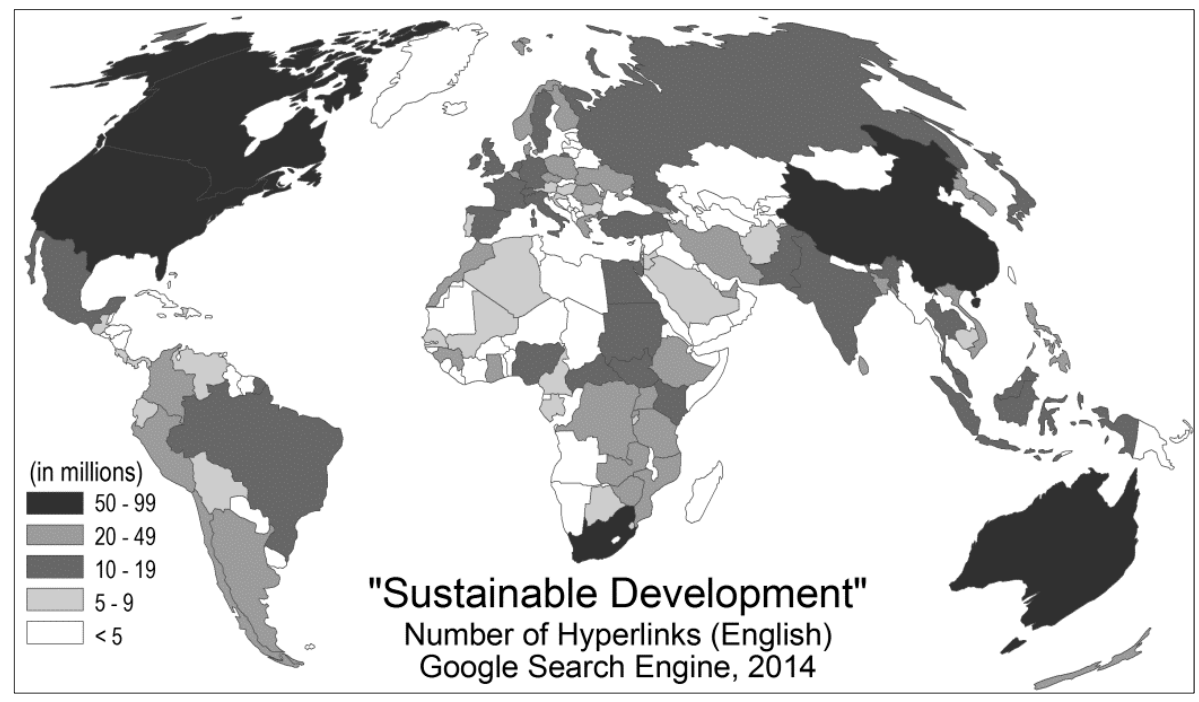

There were nearly 2.2 billion references to maps of sustainable development (Figure 8). The leading countries were slightly different than those with the most references. China was the leader with 87 million followed by Singapore at 75 million, South Africa at 55 million, Germany at 52 million and Japan at 50 million. These five had 15 percent of the total. Another 29 countries had between 20 and 49 million hyperlinks. The U.S. and Russia had about 48 million each. A number of countries in the 
Global North and South had similar numbers: Suriname, Italy, Brazil, Canada, Mauritania, Lithuania and Mexico had about 35 million each. India and Gambia had about 30 million each and Australia and Bangladesh had about 22 million each. Twenty-eight countries had between 10 and 19 million hyperlinks and 40 between 5 and 9 million. There were 96 countries that had fewer than 5 million; and of these 13 had fewer than 2 million with the fewest in St. Vincent and the Grenadines $(670,000)$, Trinidad and Tobago (650,000), Guinea-Bissau $(600,000)$ and St. Kitts and Nevis $(360,000)$. As in the case of overall sustainability label, there was much variation at regional and subregional levels.

Figure 8. "Sustainable development maps" number of hyperlinks (English) (google search engine, 2014).

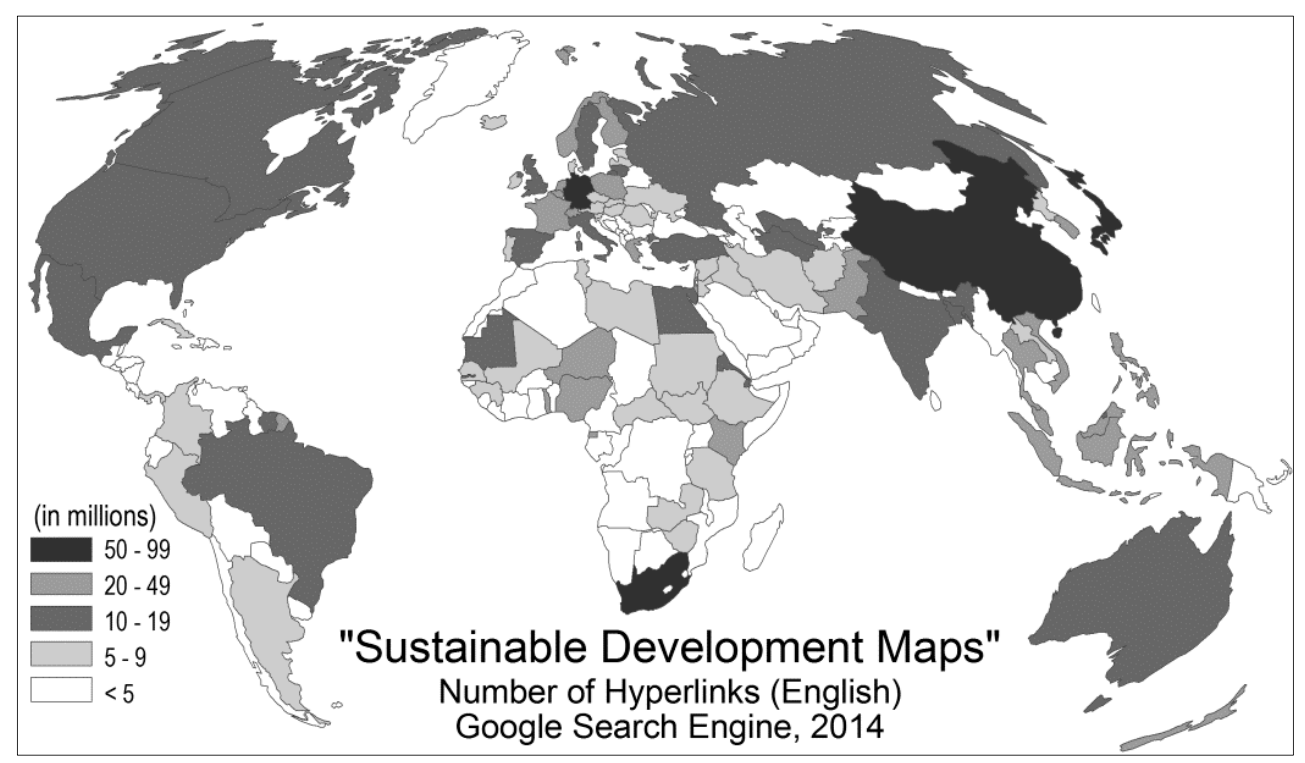

There were slightly more hyperlinks with photographs about sustainable development than maps. The 2.4 billion photos displayed examples of agriculture, forestry, mining and fishing projects, but also community development initiatives, workers, health care, improved water systems, recycling and green developments. The leading countries were South Africa with 92 million, Vatican 87 million, South Sudan 81 million, United States 74 million, and China and India with 61 million each (Figure 9). These six countries had 19 percent of all sustainable photos. Three countries (Canada, Japan and Australia) had from 40 to 49 million photos about sustainability and seven countries (United Kingdom, South Korea, Algeria, Russia, Egypt, New Zealand and Germany) had between 30-39 million. Sudan and Turkey had about 20 million each and Mauritania and Brazil about 24 million. Forty-six countries had between 10 and 20 million photos and 17 had between 5 and 10 million. There were 93 countries that had fewer than five million photos about sustainability. Not unexpectedly, and following the trend observed on the previous maps, the island countries in the Pacific and Caribbean were among those with the fewest photos; East Timor $(580,000)$, Kosovo $(680,000)$, St. Lucia $(660,000)$, East Timor $(580,000)$. 
Figure 9. "Sustainable development photos" number of HYPERLINKS (English) (google search engine, 2014).

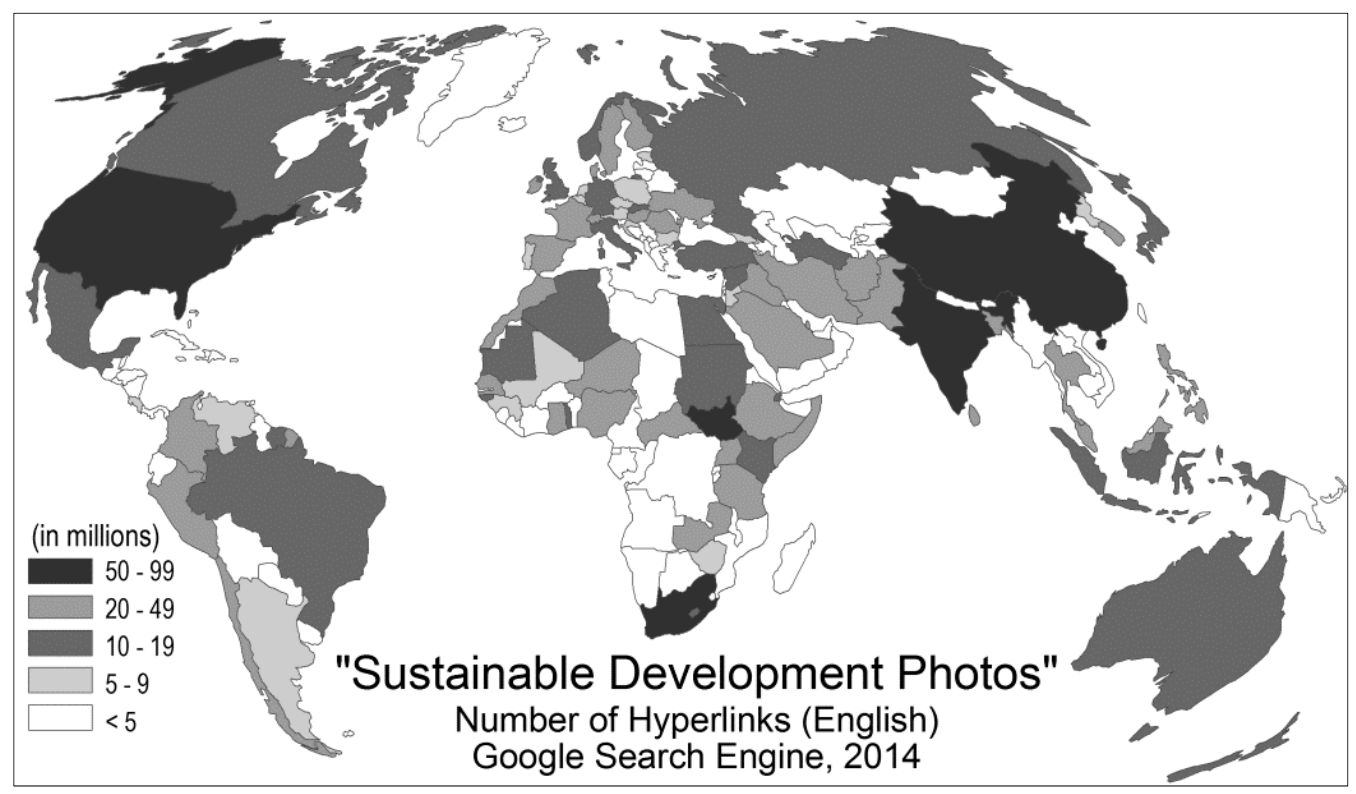

Comparing the three cyberspace maps reveals three distinct patterns. First, the largest countries generally have the most hyperlinks about sustainable development; China, the U.S., and Australia are usually in the highest or next highest categories. Mexico, Brazil, Indonesia and Egypt are in the second highest categories while Nigeria, Pakistan and Bangladesh are usually in the third categories. Second, most Sub-Saharan Africa countries, except for South Africa, are usually are in the lowest map categories; that is, they have the fewest references to sustainable development, plus the fewest maps and photos. Third, there are sharp regional differences within Europe and the Middle East. While there are more references to northern European countries, there are usually far fewer for countries in much of eastern and southeastern Europe. Latin America, like Sub-Saharan Africa also exhibits a fair amount of diversity, for example between Brazil and Argentina and Paraguay. Ministates in Africa, the Caribbean and Pacific tend to have the fewest hyperlinks in all categories; many not shown because of their small size.

\section{Discussion}

The Google data on sustainability, the volume of hyperlinks about sustainability as maps and photos, sustainability journals and countries represented by journal editors and editorial boards illustrate that there are side discrepancies or gaps in our knowledge base about sustainability. Eight noteworthy findings emerge from the data and analysis.

First, the subject matter about sustainability and sustainable development reflects a very uneven knowledge base. Topics such as health, energy, water, policy, development and planning are very popular and common themes, as measured by Google search engine hyperlinks and those associated with Google Scholar. Other topics and themes are much less the focus scholarly attention. Religion, tourism, gender, aquaculture and NGOs are examples. Boundaries in cyberspace are part of the knowledge base of what we know about sustainability. 
Second, the world maps illustrate a very uneven geographical coverage of topics related to sustainability and sustainable development. The maps not only show variations in the number of hyperlinks associated with individual countries, but also global and regional variations in the number of maps and photos with sustainable topics. European and North America countries, and also much of the rich world, have the largest numbers of photos and maps with sustainable themes, while the fewest are in Sub-Saharan African countries and Pacific and Caribbean islands. The sustainability maps illustrate a key geographical component of global sustainability, viz., that geographical boundaries do indeed make a difference. There are often clear and sharp differences between not only in bordering countries in the same region, for example between eastern and western Europe and on the South American continent, but also among countries traditionally grouped by geographers in the same region.

Third, while there are great variations in the printed, cartographic and visual worlds of sustainability and sustainable development, there is much more global coverage of those in editorial roles and serving on editorial boards. This finding was one of the unexpected results of this inquiry. The maps show countries with both editors and board members not only from North America, Europe and East Asia (especially China and Japan), but also from Sub-Saharan Africa (especially South Africa and Nigeria), the Middle East (especially Turkey), South Asia (especially India), Latin America (especially Brazil and Mexico), and the Caribbean (Cuba, Haiti and Puerto Rico). The largest number of editors and editorial board members come from the United States, United Kingdom and China. It is also encouraging that studying sustainable issues on a global scale is recognized by disciplinary and interdisciplinary journal editors, and by professional societies and associations, who see merit in crossing geographic boundaries and including scholars from more than Europe, North America, and East Asia.

Fourth, as the maps clearly point out, the U.S. clearly dominates the editorships and editorial boards of professional journals related to sustainability and sustainable development. This observation applies whether one is looking at engineering, architecture, agriculture, water, energy, development, manufacturing, communications, transportation, policy, or urban themes. As noted above nearly one-quarter of all editors and editorial board members come from the United States. The second and third ranked countries, the United Kingdom and China, have large numbers, but they pale in comparison to the U.S. dominance. Thus, gaps or boundaries exist not only between countries in the Global South and North, but in the Global North as well.

Fifth, perhaps not surprising, is the fact that a number of East, Southeast, South, and Southwest Asian countries are playing major roles in global scholarly arenas. China especially emerges as one of the major international leaders both in editorial roles and having members on editorial boards. China has editors, chief editors, associate or regional editors working on these journals: Sustainability, International Journal of Sustainability, Journal of Agricultural Biotechnology and Sustainable Development, International Journal of Sustainable Development and World Ecology, Journal of Sustainable Forestry, International Journal of Strategic Management, International Journal for Sustainable Materials and Structural Systems and Journal of Sustainable Tourism. Editors also come from Japan and South Korea in East Asia, Malaysia (especially), Indonesia, and Singapore in Southeast Asia, India in South Asia, and Turkey and Saudi Arabia in Southwest Asia.

Sixth, Brazil and Mexico clearly dominate the Latin American editorial board memberships. Their combined member (58) exceeds that of all other countries combined in Central and South America and 
the Caribbean. Again, regional gaps emerge with one or two leading countries far ahead in knowledge, as well as editors and editorial board members.

Seventh, one of the surprising results from this research is that there was only editorial board member from Russia on any editorial board. This member was on Sustainable Development and Planning. There were no scholars from Central Asia, but there were several from the Baltic states and a number from east European countries, including the Czech Republic, Slovakia, Slovenia, Bosnia, Poland, Hungary, and Bulgaria.

Eighth, one can easily make a case looking at the results of the Google searches, the number of journal titles and the home countries of editors and editorial boards that English is the most desired language to publish articles on sustainability and sustainable development. The dominance is illustrated by the United States and the United Kingdom with nearly 32 percent of all editors and 44 percent of all board members. If one added Canada, Australia, New Zealand, the percentages would be higher and still higher if Malaysia, Singapore and India were added. I suspect if one looked at major scholarly journals about sustainability published in Spanish, French, German, Russian, Chinese and Arabic that the number of Google hyperlinks and citations would be much fewer than in English. I suspect many would not have as many international editors or associate editors or global editorial boards.

\section{Challenges to Studying "Knowledge Gaps" Vis-à-Vis Sustainability}

This study has clearly demonstrated that there are wide variations or "gaps" in our knowledge about sustainability as a generic concept and also when defined more narrowly with respect to specific fields and subfields. The gaps, as we have observed, are not only with respect to disciplinary and interdisciplinary subject matter, but also associated with specific countries and regions and also with maps and photographs about sustainability projects. There are clearly many and ample research opportunities for individual scholars and collaborative researchers who work across political boundaries, disciplinary boundaries and institutional boundaries. Below I list some challenges in the form of questions that face those looking at these issues.

(1) Will the "gaps" narrow and boundaries disappear? Here I raise a fundamental question about our knowledge base and boundaries within it. Will the "gaps" discussed above, geographic, subject matter, editorial board members, continue or will they narrow in the coming years with more international and interdisciplinary interests in sustainability? A legitimate follow-up study in another decade could measure whether the differences and boundaries identified and graphically depicted above have narrowed and if so, in what subject areas and in what geographic areas or regions? One could hypothesize that these gaps would narrow or the boundaries become less important. One might consider discussing these issues vis-à-vis the North-South divide and global systems thinking, especially applying the theme to scholarship aimed at improving the human condition. For example, is the "core" knowledge (associated with the Global North) increasing faster than that associated with the semiperiphery and periphery? And what role are the BRIC (Brazil, Russia, India, and China) playing in global scholarship?

(2) Who is studying Africa? As the maps clearly illustrate, there are major gaps in what we know about sustainability in Africa. What is being studied in and about Africa? And who is studying 
sustainability issues in Africa? Africans themselves or Europeans or Chinese? Are the major "pillar" or classic studies being done by Africans or with Africans and what are the impacts of these key studies on regional, not individual country, sustainable development projects [see 43]? How many "pillar" studies appear in high impact journals? And what boundaries in knowledge and publishing are most serious and deserve the attention of African and global sustainable communities?

(3) Is sustainability research clustered or piecemeal? Various authors [3,9,26,27] have raised some fascinating questions about whether the research is more regionally clustered or individual countries. These questions would be worth exploring not only with European countries but also with African and Asian contexts. Is Chinese research now or increasingly international? How does Indian scholarship compare with that of Indian scholars? These questions might also be raised with respect to "convergence research" [23,24], the extent of international and transdisciplinary research teams, and the significance of boundaries within and across subject matter areas.

(4) Where is the "cutting edge" research on various sustainability topics coming from? Here one might follow up on Buter and van Raan [9] and Barnett et al. [25,26] studies that focuses on "seed" journals and citations, especially those pioneering works associated with the Global South. Major research universities also need to be considered in this calculus. One could also look at those pioneering pieces that actually cross intellectual and disciplinary boundaries.

(5) What will other search engines tell us? While this study used the Google search engine, there are others, including those in other languages (Baidu - Chinese; Naver-Korean) that might use to study sustainability issues. How different would the results about topics, regions, maps and photos be if these were used? Comparative studies looking at a specific topic, such as soft or green energy initiatives or a specific region, such as West Africa would be useful.

(6) How about "visualizing sustainability"? In a scholarly and popular world where "images and representation" are considered more important than words or narratives, what kind of "visual" knowledge about sustainability exists? What are the major themes and topics of maps and photos associated with Europe and the Middle East or Southeast Asia and Sub Saharan Africa or Central America and Andean America? One could look at maps and photos in the scholarly literatures as well as those in regional and global funding initiatives. The creative uses of geovisualization seen in the works by Chen [47-49], Meyer et al. [26], Yarime et al. [3], and Barnett et al. [5] offer some valuable ways to depict changes in what we know and what we study.

(7) Future impact factors? What will be the impact factors of new sustainability journals? Since only about one-third of those journals examined here have impact factors (because they have just appeared), what will be their impacts on disciplinary and interdisciplinary scholarly communities in the coming years? Will there be shifts in rankings based on their international content or will those in the Global South receive, or continue to receive, lower scores? Answers to this question will also need to be examined within the context of editors and editorial board members coming from outside the Europe-North American-Australian axis. 
(8) What role for PPGIS and social media? PPGIS (Public Participation GIS) and various social media (Facebook, Twitter et al.) are recognized as up and coming ways for marginalized groups to organize, communicate and conduct grassroots as well as policy research. To what extent might these be harnessed by those promoting various sustainability development initiatives, either for individual households or communities or local governance? The extent of these new and wireless technologies relate to gender, class, income and governance offer many opportunities for study of sustainable development at all scales.

(9) What are the reward structures? Schoolman et al. [43, pp.78-79] raise an interesting set of questions about scholars engaged in interdisciplinary and transdisciplinary sustainability research programs, especially issues about hiring, funding, mentoring, and promotion. Sustainability is only one of several emerging areas of cross-disciplinary research areas, others being health care, security, geovisualization, and information science, that present challenges to traditional disciplinary and university organizational and administrative structures. These are issues that the university, corporate and governance worlds need to confront as many engaged scholars wish to and want to establish academic "homes", even if for only a few years, not a lifetime, in environments conducive to addressing and solving interdisciplinary problems. They merit rewards for their willingness to "move beyond" traditional disciplines and to cross boundaries that while not discipline or niche focused, but focused on a larger set of overarching questions regarding planetary harmony and existence.

(10) Leaning from whom? This final question raises a fundamental question about sustainability knowledge and the value of research findings. While the lion's share of what we know comes from and is associated with the Global North or rich world, the question is what can the Global North learn about sustainability from the Global South? What can the developed world learn about sustainability and water conservation, land use, governance, energy, community engagement, consumer ethics and even spiritual values from Asian, African and Latin American societies and cultures?

\section{Conclusions}

In this presentation, my objectives have been fourfold. First, I focused on our knowledge base (that is, what we know) about sustainability and sustainable development using the number of hyperlinks in the Google Search Engine and Google Scholar databases. These cybersearches revealed wide "gaps" and boundaries in sustainability knowledge related to the natural and social sciences and the humanities. These results I used to graph a series of core, semiperiphery and periphery subjects about the sustainability knowledge base. In short, for some subjects we have much information, others, very little. Second, I used these same search engines to explore what we know about sustainability in broad areas of subject matter, for example, the engineering, natural and social sciences. Not unexpectedly, there were significant differences and boundaries as well as between the two databases. Many fewer references were in the Google Scholar database. Third, I look at the home countries and scholarly networks of 69 sustainability journal editors and editorial board members to discern if these countries showed a concentration in a few countries or a broad representation of countries on the world sustainability map. The results revealed that English language countries dominated, as well as those in 
Europe and North America. The number of editors and board members coming from Asia, African and Latin American countries were far less, although not completely "blank" on the accompanying maps. China's leadership role in both editors and board members is especially noteworthy. Fourth, I look at the geographical coverage or hyperlink volume of sustainability topics, not only the broad theme of sustainable development, but also the volume of maps and photos related to sustainability. Here, there was also very wide variation, with the Global North clearly in a dominant position compared to the Global South, especially Sub Saharan Africa and selected countries in North Africa, Southwest and South Asia. The "gaps" in sustainability knowledge extended to maps and photographs about projects. I conclude by identifying for scholars some promising areas for future research, either disciplinary or interdisciplinary or national or international. There is clearly much more additional work that can be conducted by scholars in all fields and disciplines to "cross boundaries" and "narrow the gaps" in what we know about sustainability at local and global levels. These metric and cartographic analyses reveal clearly that there are challenges for both the disciplinary and interdisciplinary scholars and teams who need to cross existing boundaries (real or imagined) to improve the human condition of those in both living, working, and leisuring in the Global South and Global North.

\section{Acknowledgments}

I want to thank Richard Gilbreath and Jeff Levy from the Gyula Pauer Cartography Center in the Department of Geography at the University of Kentucky for preparing the graphics and maps for this article and Donna Gilbreath for proofreading and formatting the article. Their skilled cartographic eyes enhance the visual quality of this presentation. Additionally, I thank the reviewers for their constructive suggestions on reorganizing and conceptualizing the paper [54,55].

\section{Conflicts of Interest}

The author declares no conflicts of interest.

\section{References}

1. Bettencourt, L.M.A.; Kaur, J. Evolution and structure of sustainability science. Proc. Natl. Acad. Sci. USA 2011, 108, 19540-19545.

2. Kates, R.W. From the Unity of Nature to Sustainability Science: Ideas and Practice. Center for International Developpment, Working Paper 218, Harvard University, Cambridge, MA, USA, 2011.

3. Yarime, M.; Takeda, Y.; Kajikawa, Y. Towards an institutional analysis of sustainability science: A quantitative examination of the patterns of research collaboration. Sustain. Sci. 2010, 5, 115-125.

4. Kajikawa, Y.; Ohno, J.; Takeda, Y.; Matsushim, K.; Komilyama, H. Creating an academic landscape of sustainability science: An analysis of the citation network. Sustain. Sci. 2007, 2, 221-231.

5. Kates, R.W. What is sustainable development? Goals, indicators, values and practice. Environment 2005, 47, 8-21.

6. Parris, T.M.; Kates, R.W. Characterising and measuring sustainable development. Ann. Rev. Environ. Resour. 2003, 28, 559-586. 
7. Clark, W.C.; Dickson, N.M. Sustainability science: The emerging research program. Proc. Natl. Acad. Sci. USA 2003, 100, 8059-8061.

8. Castells, M. The Rise of the Network Society: The Information Age: Economy, Society and Culture; Blackwell: Oxford, UK, 1996.

9. Buter, R.K.; van Raan, A.F.J. Identification and analysis of the highly cited knowledge base of sustainability science. Sustain. Sci. 2013, 8, 253-267.

10. Bakkalbasi, N.; Bauer, K; Glover, J.; Wang, L. Three options for citation tracking: Google Scholar, Scopus and Web of Science. Biomed. Digit. Libr. 2006, 3, 7. doi:10.1186/1742-5581-3-7.

11. Bauer, K.; Bakkalbasi, N. An examination of citation counts in a new scholarly communication environment. D-Lib Magazine, 11 (9), September 2005. Available online: http:/www.dlib.org/ september05/bauer/09.bauer.html (accessed 0n 16 September 2014).

12. Cronin, B.; Sugimoto, C.R. Beyond Bibliometrics: Harnessing Multidimensional Indicators of Scholarly Impact; MIT Press: Cambridge, UK, 2014.

13. Garfield, E. The epidemiology of knowledge and the spread of scientific information. Curr. Contents 1980, 35, 5-10.

14. Park, H.W.; Thelwall, M. Hyperlink analyses of the World Wide Web: A review. J. Com-Med. Comm. 2003, doi:10.1111/j.1083-6101.2003.tb002233.x.

15. Thelwall, M. Interpreting social sciences link analysis research: A theoretical framework. J. Assn. Inf. Sci. Tech. 2006, 57, 60-68.

16. Thelwall, M. Introduction to Webometrics: Quantitative Web Research for the Social Sciences; Morgan and Claypool Pub: San Rafael, CA, USA, 2009.

17. Thelwall, M.; Vaughan, L.; Björneborn, L. Webometrics. J. Assn. Info. Sci. Tech. 2005, 39, 81-135.

18. Wade, M.; Holland, J. The resource-based view and an information systems research: Review, extension, and suggestions for future research. J. Manag. Inf. Syst. 2004, 7, 27-46.

19. Vaughan, L.; Thelwall, M. Scholarly use of the web: What are the key inducers of links to journal web sites? J. Assn. Inf. Sci. Tech. 2003, 54, 29-38.

20. Park, H.W.; Leydesdorff, L. Knowledge linking structures in communications studies using citation analyses among communications journals. Scientomet 2009, 81, 157-175.

21. Hirsch, J.W. An index to quantify an individual's scientific research output. Proc. Natl. Acad. Sci. USA 2005, 102, 16569-16572.

22. Barnett, G.A.; Park, N.W. The structure of international internet hyperlinks and bilateral bandwith. Ann. Des Telecomm. 2005, 60, 1115-1132.

23. Barnett, G.A.; Huh, C.; Kim, Y.; Park, H.W. Citations among communications journals and other disciplines: Network analysis. Scientomet 2011, 88, 449-469.

24. Barnett, G.A.; Park, N.W.; Jiang, K.; Tang, C.; Aguillo, I.F. A multi-level network analysis of web-citations among the world's universities. Scientomet 2014, 99, 5-26.

25. Meyer, E.T.; Park, N.W.; Schroeder, R. Mapping global e-research scientometrics and webometrics. In Proceedings of the 5th International Conference on e-Social Sciences, Cologne, Germany, 24-28 June 2009.

26. Buter, R.K.; Noyons, E.C.M.; van Raan, A.F.J. Searching for converging research using field to field citations. Scientomet 2011, 86, 325-338. 
27. Buter, R.K.; Noyons, E.C.M.; van Raan, A.F.J. Identifcation of converging research areas using publications and citations data. Res. Eval. 2010, 19, 19-27.

28. Appropedia Website. Available online: http://www,appropredia.org/journals (accessed on 31 July 2014).

29. Noyons, E.C.M.; Buter, R.K.; van Raan, A.F.J. Mapping Excellence in Science and Technology across Europe: Life Science Final Report; Centre for Social and Technology Studies: Leiden, The Netherlands, 2003.

30. Shiffrin, R.M.; Borner, K. Mapping knowledge domains. Proc. Natl. Acad. Sci. USA 2001, 98, S183-S185.

31. Kousha, K.; Thelwall, M. Google Scholar citations and Google Web/URL citations: A multi-discipline exploratory analysis. J. Assn. Inf. Sci. Tech. 2007, 58, 1055-1065.

32. Kulkani, A.V.; Aziz, B.; Shams, I.; Bussa, J.W. Comparisons of citations in Web of Science, Scopus and Google Scholar for articles published in general medical journals. JAMA 2009, 302, 1092-1096.

33. Meha, L.I.; Yang, K. Impact of data sources on citation counts and rankings of LIS faculty: Web of Science versus Scopus and Google Scholar. J. Assn. Inf. Sci. Tech. 2007, 58, 2105-2125.

34. Kajikawa, Y. Research core and framework of sustainability science. Sustain. Sci. 2008, 3, 215-239.

35. Vaughan, L.; Thelwall, M. Search engine coverage bias: Evidence and possible causes. Inf. Proc. Manag. 2004, 40, 693-707.

36. Bettencourt, L.M.A.; Kaiser, D.I.; Kaur, J.; Castillo-Chavez, C.; Wojick, D.E. Population modeling of the emergence and development of scientific fields. Scienotomet 2008, 75, 495-518.

37. Bettencourt, L.M.A.; Cintron-Arias, R.; Kaiser, D.I.; Castillo-Chavez, C. The power of a good idea: Quantitative modeling of the spread of ideas from epidemiological models. Physics 2008, 364, 513-536. Available online: http://www.researchgate.net/publication/221711540_The_Power_ of_a_good_idea_Quantitataive (accessed on 12 September 2014).

38. Bettencourt, L.M.A.; Kaiser, D.I.; Kaur, J. Scientific discovery and topological translations in collaborative networks. J. Inf. 2009, 3, 210-221.

39. Kates, R.W.; Clark, W.C.; Corell, R.; Hall, J.M.; Jaeger, C.C. Sustainability science. Science 2001, 292, 641-642.

40. Kates, R.W. Readings in Sustainability Science and Technology. Center for International Development, Working Paper 213, Harvard University, Cambridge, MA, USA, 2010.

41. Melville, N.P.; Ross, S.M. Information systems innovation for environmental sustainability. MIS Quart. 2010, 34, 1-21.

42. Kajikawa, Y.; Tacoa, F.; Yamaguchi, K. Sustainability science: The changing landscape of sustainability research. Sustain. Sci. 2014, doi:10.1007/s11625-014-0244-x.

43. Schoolman, E.D.; Guest, J.S.; Bush, K.F.; Bell, A.R. How interdisciplinary is sustainability research? Analysis of the structure of an emerging scientific field. Sustain. Sci. 2012, 7, 67-80.

44. Sherren, K.; Klovdahl, A.S.; Rbin, L.; Butler, L.; Dovers, S. Collaborative research on sustainability: Myths and conundrums of interdisciplinary departments. Available online: http://jrp.icaap.org/index.php/jrp/article/view/163 (accessed on 16 September 2014).

45. Boyack, K.W.; Klavans, R.; Borner, K. Mapping the backbone of Science. Scientomet 2005, 64, 351-374. 
46. Cavena, R.; Belhave, B.L.; Sekeran, U. Applied Business Research: Qualitataive and Quantitataive Merthods; Wiley: New York, NY, USA; Sydney, Australia, 2011.

47. Chen, C. Searching for intellectual turning points: Progressive knowledge domain visualization. Proc. Natl. Acad. Sci. USA 2004, 101, S303-S310.

48. Chen, C. Turning Points: The Nature of Creativity; Springer: Dordrecht, The Netherlands, 2012.

49. Chen, C. Mapping Scientific Frontiers the Quest for Knowledge Visualization; Springer: Dordrecht, The Netherlands, 2013.

50. McCain, K.W. Mapping authors in intellectual space: A technical overview. J. Assn. Inf. Sci. Tech. 1999, 41, 433-443.

51. International Union for the Conservation of Nature and Natural Resources (IUCN). World Conservation Strategy: Living Resource Conservation for Sustainable Development; IUCN: Gland, Switzerland, 1980.

52. Levin, S.; Clark, W.C. Report from Towards a Science of Sustainability Conference; Sustainability Science Program, Harvard University: Cambridge, MA, USA, 2010.

53. National Research Council; Board on Sustainable Development. Our Common Journey: A Transition Toward Sustainability; National Academy Press: Washington, DC, USA, 1999. Available online: http://www.nap.edu/catalog.phy"record_id=9690 (acessed on 12 September 2014).

54. Schellinhuber, H.J.; Molina, M.; Stern, N.; Huber, V.; Kadner, S. Global Sustainability: A Noble Cause; Cambridge University Press: Cambridge, UK, 2010.

55. United Nations. Agenda 21 Report of the United Nations Conference on Environment and Development; United Nations: Rio de Janeiro, Brazil, 1992. Available online: http:// sustainabledevelopment.un.org/content/documents/Agenda21.pdf (acessed on 12 September 2014).

(C) 2014 by the author; licensee MDPI, Basel, Switzerland. This article is an open access article distributed under the terms and conditions of the Creative Commons Attribution license (http://creativecommons.org/licenses/by/4.0/). 